\title{
Teaching Video NeuroImages: Hourglass-like fascicular constriction in Parsonage-Turner syndrome
}

Stephan Mittas, MD, and Einar Wilder-Smith, MD

Neurology ${ }^{\circledR}$ 2019;92:e2399-e2400. doi:10.1212/WNL.0000000000007512

Figure 1 Ultrasound, intraoperative photograph, and histopathology
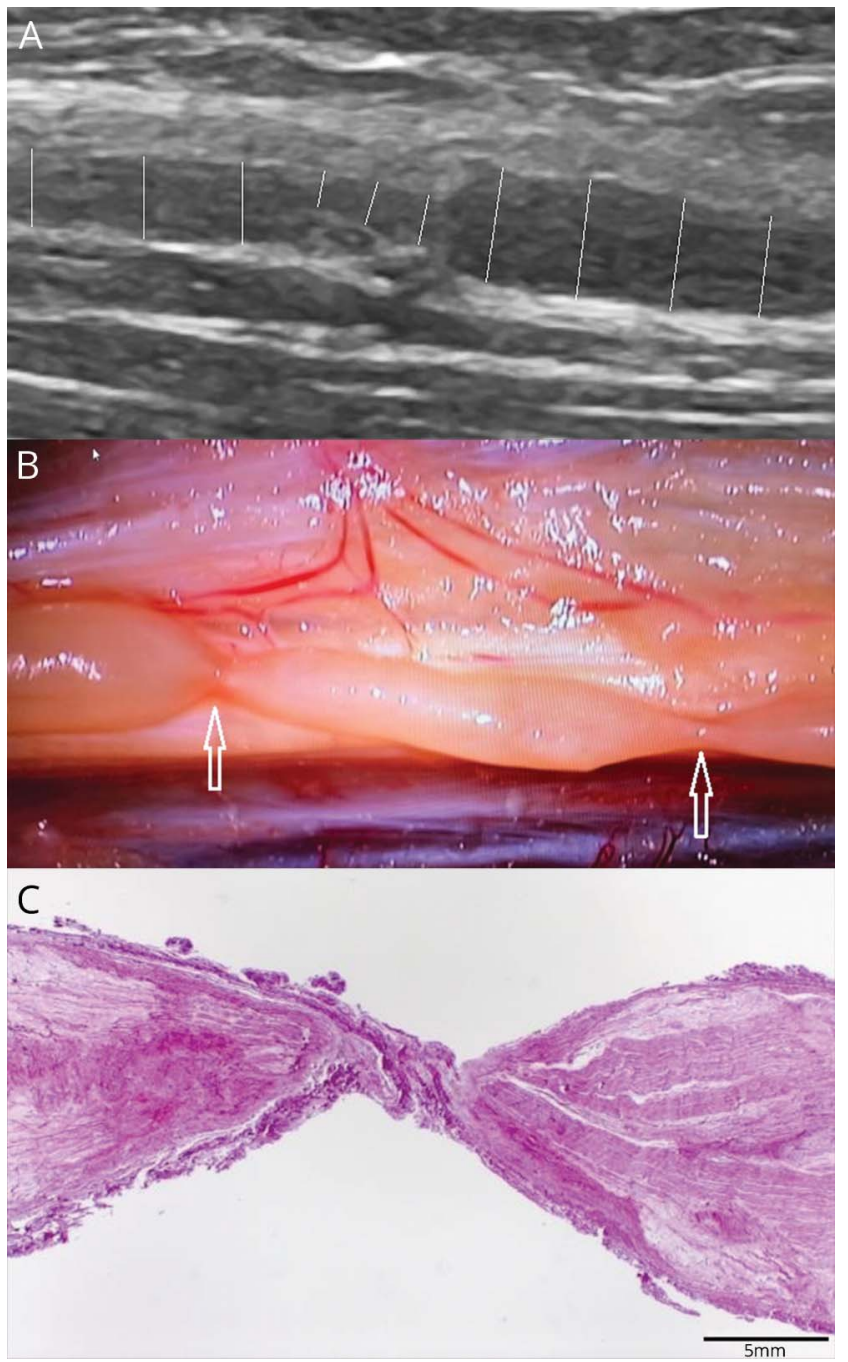

(A) Longitudinal ultrasound section of an anterior interosseous nerve fascicle in the median nerve at elbow level, hourglasslike, torsional constriction (distal constriction; proximal constriction not shown). (B) Intraoperative confirmation of 2 constrictions (thick arrows) with slight torsion at internal neurolysis; fascicular grafting followed. (C) Histology of resected fascicle with subtotal loss of vital nerve tissue within the constriction; note the torsional appearance.

A 43-year-old woman presented with intense pain in the left upper arm, a plegic flexor pollicis longus, and flexor digitorum profundus of the 2 nd digit without sensory symptoms
Correspondence

Dr. Mittas

stephan.mittas@luks.ch

\section{MORE ONLINE}

- Video

$\rightarrow$ Teaching slides

links.lww.com/WNL/

A886

From the Department of Neurology (S.M., E.W.-S.), Luzerner Kantonsspital, Switzerland; and Department of Medicine (E.W.-S.), Yong Loo Lin School of Medicine, National University Singapore. Go to Neurology.org/N for full disclosures. Funding information and disclosures deemed relevant by the authors, if any, are provided at the end of the article. 

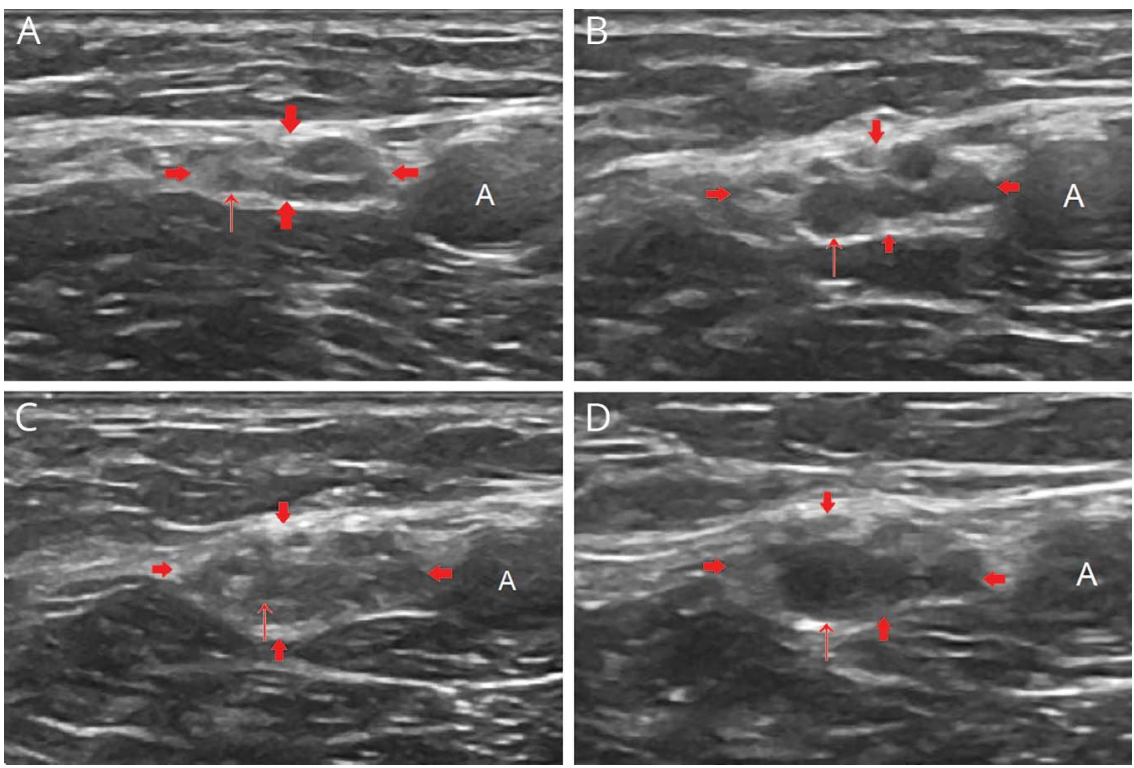

Preoperative dynamic ultrasound of the median nerve (filled arrows) in cross-sectional view with inhomogeneous fascicular diameters, from distal to proximal. Thin arrows: prominent fascicle with constrictions and swellings at the level of $(A)$ the distal constriction, (B) between constrictions, (C) the proximal constriction, and (D) the adjacent, proximal, "ballooned" swelling.

occurring 8 days after a hysterectomy. Needle myography showed acute denervation and absent volitional motor activity of affected muscles. The patient was diagnosed with Parsonage-Turner syndrome (PTS) (figures 1 and 2, video 1$)$.

PTS or neuralgic amyotrophy presents with subacute intense extremity pain, followed by patchy axonal lesions of upper extremity or plexus nerves. The combination of long thoracic and anterior interosseous nerve affections is almost pathognomonic. Recently, hourglass-like fascicular constrictions and torsions have been observed in the clinical context of neuralgic amyotrophy. ${ }^{1,2}$

\section{Study funding}

No targeted funding reported.

\section{Disclosure}

The authors report no disclosures relevant to the manuscript. Go to Neurology.org/N for full disclosures.

\section{References}

1. Aranyi Z, Csillik A, Devay K, et al. Ultrasound identification of nerve pathology in neuralgic amyotrophy: enlargement, constriction, fascicular entwinement and torsion. Muscle Nerve 2015;52:503-511.

2. Pan YW, Wang S, Zhen D, et al. Hourglasslike constrictions of peripheral nerve in the upper extremity: a clinical review and pathological study. Neurosurgery 2014;74: $10-22$. 


\section{Neurology}

\section{Teaching Video NeuroImages: Hourglass-like fascicular constriction in Parsonage-Turner syndrome}

Stephan Mittas and Einar Wilder-Smith

Neurology 2019;92;e2399-e2400

DOI 10.1212/WNL.0000000000007512

\section{This information is current as of May 13, 2019}

\section{Updated Information \& Services}

\section{References}

\section{Subspecialty Collections}

\section{Permissions \& Licensing}

Reprints including high resolution figures, can be found at: http://n.neurology.org/content/92/20/e2399.full

This article cites 2 articles, 0 of which you can access for free at: http://n.neurology.org/content/92/20/e2399.full\#ref-list-1

This article, along with others on similar topics, appears in the following collection(s):

Autoimmune diseases

http://n.neurology.org/cgi/collection/autoimmune_diseases EMG

http://n.neurology.org/cgi/collection/emg

Other Education

http://n.neurology.org/cgi/collection/other_education

Peripheral neuropathy

http://n.neurology.org/cgi/collection/peripheral_neuropathy

Ultrasound

http://n.neurology.org/cgi/collection/ultrasound

Information about reproducing this article in parts (figures,tables) or in its entirety can be found online at:

http://www.neurology.org/about/about_the_journal\#permissions

Information about ordering reprints can be found online:

http://n.neurology.org/subscribers/advertise

Neurology ${ }^{\circledR}$ is the official journal of the American Academy of Neurology. Published continuously since 1951, it is now a weekly with 48 issues per year. Copyright @ 2019 American Academy of Neurology. All rights reserved. Print ISSN: 0028-3878. Online ISSN: 1526-632X.

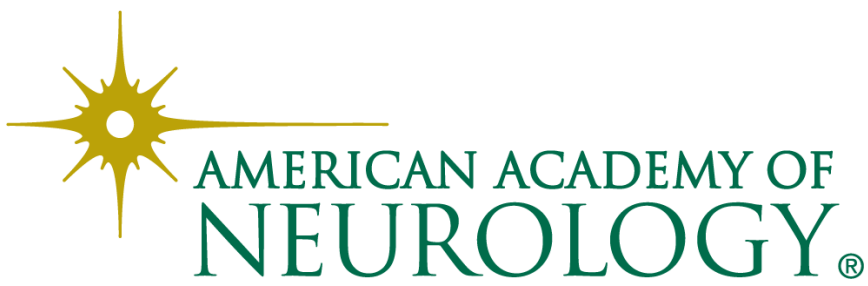

